\title{
The Effect of Problem Based Learning Model by Animation Media on Student Learning Outcomes in Senior High School on Chemical Bonding Topic
}

\author{
Faderina Komisia* and Maria Aloisia Uron Leba \\ Chemistry Education Program, Faculty of Teacher Training and Education, \\ Universitas Widya Mandira \\ Kupang, East Nusa Tenggara, Indonesia \\ faderinakomisia23@gmail.com
}

\begin{abstract}
The purpose of this research are (1) to know the differences of students learning outcome who are taught using problem based learning model with animation media with problem based learning model without animation media and conventional learning on chemical bonding topic (2) to know the differences of students learning outcome who are taught using problem based learning model with animation media and conventional learning on chemical bonding topic. (3) to know the differences of students learning outcome who are taught using problem based learning model without animation media and conventional learning on chemical bonding topic. The sample of research were $10^{\text {th }}$ grade students of MIPA 1, MIPA 2, and MIPA 3 SMAN 6 Kupang. The research design used was post-test only control group design. The students learning outcome data was collected by test technique. The significance differences in students learning outcome were analyzed by ttest and oneway ANOVA. The results showed that (1) Learning outcomes of students taught using problem based learning models with animation media were significantly different from students taught using problem based learning models without animation media and from students taught using conventional learning on chemical bonding topic, higher learning outcomes of students taught with problem based learning model with animation media $(82.03>79.56>75.50)(2)$ Learning outcomes of students taught using problem based learning models with animation media were significantly different from students taught using conventional learning on chemical bonding topic, higher learning outcomes were students taught with problem based learning models with animation media $(82.03>75.50)$. (3) Learning outcomes of students taught using problem based learning models without animation media were significantly different from students taught using conventional learning on chemical bonding topic, higher learning outcomes were students taught with problem based learning models without animation media $(79.56>75.50)$.
\end{abstract}

Keywords-Problem based learning models, animation media, student learning outcomes, chemical bonding.

\section{INTRODUCTION}

Problem based learning is a student centered learning model. Problem based learning empowers students to do research, integrate theory and practice, and apply knowledge and skills to develop an active solution to solve problems. Animated learning media is media that contains a collection of images that are processed in such a way so as to produce movement and equipped with audio so memorable and life- saving messages of instruction [1]. Animation media in learning aims to maximize visual effects and provide continuous interaction so that understanding of teaching materials increases. One of the causes of student failure in the learning process is because students are never stimulated to search, find, and explore so that students learn not only at school but also can use the universe, the environment and the surrounding technology.

One of the chemistry topic that is difficult to be understood by students is the chemical bonds because they are abstract. The abstract part is the release of electrons, the acceptance of electrons, the transfer of electrons, the occurrence of bonds between atoms / elements, making it difficult for students to understand. Without understanding this part, it is difficult for students to distinguish between covalent bond and coordination covalent bond, understanding the bonds between elements (ionic bonds, covalent bonds, and metal bonds). Besides that it is caused by the presentation of material that is less interesting and boring.

Generally the teachers only emphasize the use of conventional learning, teachers rarely involve students in the learning process, rarely use instructional media in delivering material and there is no interaction in learning, because the learning process lasts only one direction. To overcome these educational problems, it is necessary to work on improving learning as a strategy to improve student learning outcomes by means of how chemical materials can be packaged into interesting and easy to understand lessons. One of the learning model that can empower students and can facilitate students to learn is Problem Based Learning (PBL) model. In addition, the use of moving images in the description of chemical concepts, in addition to concretizing the abstract chemistry concepts, can also add to the strength of rein formation and can increase students' interest and attention throughout the teaching and learning process.

Problem based learning model with animation media on chemical bond topic is expected to improve the students learning outcomes. In this paper, we reported the results of research about the influence of problem based learning models by animation media on student learning outcomes at senior high school on chemical bonding topic. 


\section{METHODS}

This type of research is experimental research with the posttest only control group design [2]. This research was carried out at SMAN 6 Kupang, East Nusa Tenggara, indonesia. The sample in the study were the $10^{\text {th }}$ grade students of MIPA 1, MIPA 2, MIPA 3 SMAN 6 Kupang. This research was carried out at the odd semester of academic year 2018/2019. The students learning outcome data were collected by test technique. Data obtained from research were analyzed by t-test and one way ANOVA using SPSS program.

\section{RESULTS AND DISCUSSIONS}

Based on the research, it was obtained the following data, namely: 1). Student learning outcomes after attending the chemistry learning using problem-based learning model with animation media. 2). Student learning outcomes after taking the chemistry learning using problem-based learning model without animation media and 3). Student learning results after involving in the chemistry conventional learning.

Based on the results of data analysis, the $\mathrm{F}>\mathrm{F}_{\text {table }}$ values $(54.412>3.094)$ were obtained from the first research objective. Based on the hypothesis testing criteria, then Ho was rejected and $\mathrm{Ha}$ was recieved, its mean that the learning outcomes of students taught using problem-based learning models with animation media were significantly different from students taught using problem-based learning models without animation media and with students taught using conventional learning on chemical bonding topic. The higher student learning outcomes were achieved by students taught using problem-based learning models with animation media (mean value: $82.03>79.56>75.50$ ). At the second goal was obtained that the learning outcomes of students taught using problem-based learning models with animation media were significantly different from students taught using conventional learning on chemical bonding topic $(\mathrm{t}>$ $t_{\text {table }}$ or $\left.8.76>1.999\right)$. the higher student learning outcomes were achieved by students taught using problem based learning models with animation media (mean value: $82.03>$ 75.50). At the third goal was obtained that the learning outcomes of students taught using a problem-based learning model without animation media were significantly different from students taught using conventional learning on the chemical bonding topic $\left(\mathrm{t}>\mathrm{t}_{\text {table }}\right.$ or $\left.8.76>1.999\right)$. the higher student learning outcomes were achieved by students taught with problem-based learning models without animation media (mean value: $79.56>75.50$ ).

Result of research showed that the chemistry learning on chemical bonding topic using problem-based learning models with animation media gave the highest of learning outcomes of students compared with problem-based learning models without animation media and conventional learning. Yamin stated that problem based learning was an innovative learning model that provided active learning conditions to students in real world conditions [3]. Based on several opinions of experts, researchers concluded that problem-based learning was a learning model that emphasizes the provision of stimuli to students in the form of presenting a contextual problem that must be solved by exploring students' knowledge and experience. Through problem-based learning, students will be more active and motivated to learn because it will increase students' curiosity in solving a problem. The concept of ion bond formation, dissolution of ionic compounds, covalent bond formation, and covalent bond polarization are actually abstract concepts that students sometimes find difficult to understand.

The role of learning media as a tool can bridge abstract concepts as if they were concrete through visualization. One of visualization technique is to use computer media in the form of animation. Animation at the molecular level can encourage effective learning processes [4]. By visualizing (animation techniques) on the concept, it can show the relationship that occurs at the submicroscopic level with the macroscopic level. According to Sweller (Tasker, 2006), the level of complexity of information or material being studied (intrinsic cognitive content), can be minimized through good material presentation techniques. When intrinsic cognitive load becomes minimum, followed by extrinsic cognitive charge (material presentation technique), it is likely to occur the process of knowledge acquisition, so that working memory can organize, construct, encode, elaborate and integrate the material being studied as knowledge stored properly in long term memory.

Audio-visual presentation is considered to be able to help students understand concepts that have been considered difficult. According to Meyer, multimedia learning must have several basic principles including: 1) multiple representation principle, explanation that requires multi representation both visual and verbal. 2) contiguity principle, explanation of multimedia must have the appropriate connection. 3) split attention principle, words that are presented auditory (pronounced) are better than visually in the form of text on the screen [5].

Problem based learning model with the animation media applied by the teacher on chemical bond learning in this study influenced the learning outcomes of chemistry students in Senior High School, namely the results of students' chemistry learning on the material of chemical bonds to be better. The average results of students' chemistry learning in learning chemical bonds in problembased learning models with animation media are higher. This is because, the teacher uses a varied learning model in the learning of this chemical bond so that students become more interested, not bored, more enthusiastic and easier to understand ionic and covalent bonding material which has been considered a difficult material and is an abstract concept. With a problem based learning model that uses this animation media, ion and covalent bonding material which is an abstract concept can be concrete through the visualization given by the teacher in classroom learning.

Visualization given in this study was through animated videos shown using power point like animated videos on ionic and covalent bond formation processes. With this animation media, it is easier for students to understand this ionic and covalent bonding material, so that student learning outcomes become better. From this research, it can be seen that the varied learning models used by the teacher in the learning process in the classroom can improve student learning outcomes. 


\section{CONCLUCSIONS}

The conclusions in this study are as follows:

1. The learning outcomes of students resulted from implentation the problem based learning models with animation media were different from the problem-based learning models without animation media and the conventional learning on chemical bonding topic. The higher student learning outcomes was obtained from implementation the problem-based learning models with animation media.

2. The learning outcomes of students was obtained from implementation the problem-based learning models without animation media was different from students who are taught using conventional learning on chemical bonding topic. The higher learning outcomes of students were gained by problem-based learning model without animation media.
3. The highest of learning outcomes of students was resulted from implementation of the problem based learning models with animation media.

\section{REFERENCES}

[1] Furoidah. Animation as Learning Media. Surabaya: Mentari Pustaka, 2009.

[2] Sugiyono. Education Reseach Method (Quantitative, Qualitative, and R\&D Approach). Bandung: Alfabeta, 2008.

[3] Yamin, M. Startegy and Method in Learning Model. Jakarta: Referensi (GP Press Group), 2013.

[4] Tasker, R \& Dalton, R. "Research into practice: Visualization of the molecular world using animations". Chem. Educ. Res, 2006, Prac. 7, pp: 14.

[5] Allen. N.J., Meyer, J.P \& Smith, C.A. "Commitment to organizations and occupations: Extension and test of a three-component conceualization", Journal of Applied Psychology, 1997, Vol. 78, No. 4, pp: 538-351. 